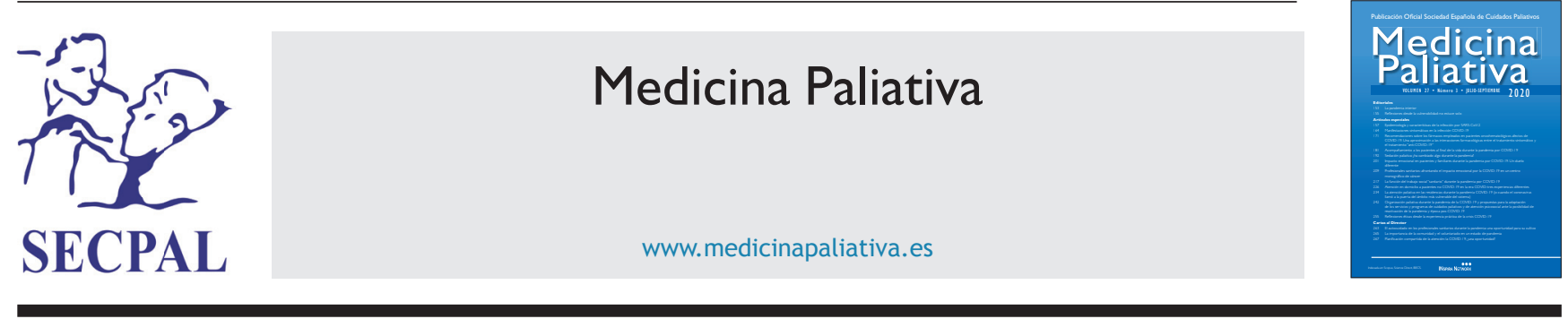

\title{
Reflexiones desde la vulnerabilidad: no estuve solo
}

Tras padecer la COVID-19 decidí escribir mi experiencia de la enfermedad en cierto modo como una terapia personal, pero sobre todo como una forma de agradecimiento hacia las personas que me quieren y cuya cercanía he sentido: familia, amigos, colegas universitarios, compañeros sanitarios, pacientes y estudiantes. No estuve solo.

Me piden ahora que haga públicos algunos fragmentos de este relato íntimo y he seleccionado estas líneas, sobre todo con el deseo de homenajear a los profesionales de todos los estamentos que han formado parte de esta admirable comunidad de cuidados. Aspiro a que esta reflexión, sobre unos momentos para mí inolvidables, nos ayude a valorar lo que tenemos: la profesionalidad y la grandeza del trabajo en equipo en el cuidado de las personas que sufren.

Llevaba tres días encontrándome mal y supe que estaba infectado tras una llamada telefónica que me puso en alerta, porque varios asistentes a nuestra reunión del 4 de marzo de 2020 ya habían dado positivo al test del coronavirus. No se me había pasado por la cabeza. La verdad es que en mi inconsciencia me sentía inmune. Eran los demás quienes podían estar enfermos, y a mí me correspondía cuidarles.

\section{LOS SÍNTOMAS Y MI PARTICULAR TEORÍA FISIOPATOLÓGICA}

El "quebrantamiento general" es una expresión magistral de la literatura médica, pero si no lo sufres en tus carnes no tienes ni idea de lo que dices cuando utilizas este término. Te sientes quebrado, aserrado, troceado, aplastado, apaleado..., y, además, con una agitación por el dolor que te impulsa a levantarte, pero entonces te agarra por el cuello la debilidad, que te hunde en la cama como si tuviera varios metros de profundidad.

Reflexionando (en el aislamiento, la razón y el delirio se dan la mano), he llegado a concluir que este coronavirus, cuando se apodera de ti, ataca a través de dos mecanismos: uno salvaje y otro bioquímico. El mecanismo salvaje es por mordedura. Notas que el virus te tritura la carne. Es como unos perros que sobre todo atacan por la noche, al amparo del silencio y la oscuridad. Me venía a la cabeza la novela de lan McEwan titulada Los perros negros ${ }^{1}$, que aparecen como espectros en su portada. Quien se sonría por mi imaginación febril debe saber que, posteriormente, esta descripción se la he oído literalmente al exjugador de baloncesto Alfonso Reyes en una entrevista en la radio, quien postrado por el coronavirus explicaba: "ya empieza de nuevo a morderme el perro".

Hablemos ahora de la debilidad que se corresponde con el segundo mecanismo de actuación del bicho que he denominado "bioquímico", en mi peculiar teoría fisiopatológica. Pienso que el coronavirus entra en las células y se apodera de las mitocondrias, esas baterías con forma de habichuela donde se genera la energía que nos mantiene encendidos. Es decir, el ataque del virus a las células reduce a niveles ínfimos la fabricación del ATP. La consecuencia es que sientes una debilidad infinita. Cuando me tenía que levantar al baño caminaba encorvado como un anciano de 100 años, y al hablar por el móvil sacaba un hilillo de voz que tenía a mi familia espantada pensando que me perdían para siempre; de hecho, evitaba coger las llamadas, pero claro eso tampoco les tranquilizaba demasiado...

Pensarán que me estoy dejando la afectación respiratoria, que es lo más grave de esta infección, que puede aparecer hacia los 7-12 días de evolución. Bueno, pues yo no he tenido ni tos, ni apenas disnea, y por tanto, aparentemente, mi caso, a pesar de su intensidad, no me afectaba a los pulmones. Luego supe que los crepitantes también estuvieron merodeando y amenazando. En cualquier caso, según mi rupestre y atrevida explicación fisiopatológica, el daño pulmonar es fácil de explicar con el mecanismo "salvaje" del virus, que muerde y tritura los alveolos, afectando el intercambio gaseoso, de ahí la importancia de vigilar la saturación de oxígeno. Cuando el destrozo y la consiguiente inflamación es importante, se produce la neumonía; y cuando la intensidad de la inflamación pulmonar compromete seriamente la respiración, y la administración de oxígeno ya no basta, se hace necesaria la intubación con el ingreso en la UCl. 


\section{EL PERSONAL SANITARIO: LAARISTOCRACIA DEL HUMANISMO}

Tras una primera semana en casa, aislado en mi habitación, me tuvieron que llevar a urgencias: llevaba tres días sin comer y, lo más preocupante, sin beber, ya que el agua me repugnaba, no me entraba ni a sorbos, como si tuviera la rabia. El instinto me decía que o entraba líquido o acabaría siendo pasto de la medicina forense. Aterricé de madrugada en una de las salas de observación de urgencias de un gran hospital. Tras ponerme un gotero y gafas de oxígeno pensé aliviado "por lo menos no termino con un fallo renal”. Noche toledana de dolores increíbles. Al principio era el único enfermo de la sala, pero pronto empezó un desfile de pacientes que iban llegando como si fuera un hospital de campaña después de la batalla. Por la mañana todo lleno. Una doctora me hizo la exploración de rigor, pero antes me dijo que hace años fue residente en mi centro de salud. Qué quieren que les diga, eso me gustó, sobre todo por el cariño que puso al retirarse la mascarilla un poco para que la pudiera reconocer. De allí rumbo a la planta COVID, donde iba a pasar los días más duros y tremendos de mi vida.

La disciplina hospitalaria es implacable. Entran a limpiar a primera hora y vuelven por la tarde. La limpiadora saluda, pide permiso para ventilar y procede con una sistemática metódica y casi científica que, yo embozado, observaba admirado. Por mi extrema debilidad me sentía hundido en la cama. Un día me forcé a decir algo con la vocecilla que pude sacar: "Oiga, para limpiar así habrán recibido cursos, ¿verdad?”. Respuesta: “Limpiar es muy fácil. Lo importante es saber arrancar una sonrisa al paciente". ¡Toma ya! El nivel del colchón se recuperó durante un rato de su hundimiento.

Las auxiliares pasan a hacerte la cama y, si hace falta, te ayudan en el aseo personal. Por mi edad preguntaban: “¿Usted es autónomo, verdad?" Con gran esfuerzo explicaba que, aunque no soy un anciano, estoy "hecho unos zorros”; justo me da para ponerme de pie y necesito que me den un fregoteo con esas esponjas mágicas. Y así lo hacían, con extremo cuidado y delicadeza.

Un día me dejaron en la mesilla una cuartilla de parte de una enfermera: “Hola, Rogelio. Soy Alejandra, una de las enfermeras que ha estado cuidándote. Te escribo esta carta para que sepas que no estás solo, que todas nosotras te estamos cuidando y acordándonos de ti en cada momento. Luchando médicos, enfermeras, auxiliares, limpieza, todo el personal del hospital juntos, para que te mejores y pronto puedas estar en casa. ¡Juntos vamos a superarlo! No queremos que decaiga ese ánimo, ya que todo va a ir genial. Aprovecho para despedirme, ya que es mi último día aquí, pero se queda contigo un gran equipo para cuidarte y yo sigo cuidando de otros enfermitos en estos días. Un abrazo. Tu enfermera”.

No me digan que no es emocionante. ¿Qué hemos hecho para merecer gente con este corazón? Al releer la carta se me humedecen los ojos. ¿Labilidad emocional de la convalecencia? Piensen lo que quieran. He quedado muy impactado por la profesionalidad de todo el personal. Se notaba que estaban crecidos. Esto traduce un componente vocacional muy fuerte. Conste que no toco de oídas, porque soy profesor de Ética en Medicina y tengo el tema trabajado. Recientemente he dirigido una tesis doctoral sobre la compasión, y estoy impresionado por la cantidad de citas que recibe el artículo que la doctoranda ha publicado ${ }^{2}$. Me parece muy alentador que la compasión despierte tanto interés en el mundo de la salud, pero sentirlo aplicado a tu propia persona es algo especial. Y esto no es solo una cuestión de sentimientos, porque la compasión profesional es empatía y comprensión para ayudar al paciente de un modo efectivo. Ahora no puedo detenerme en matices, pero quería levantar acta de esta experiencia que ustedes sabrán valorar.

Para mis colegas en la medicina necesitaría un capítulo aparte, con un agradecimiento especial hacia la doctora que fue la responsable principal de mi atención. Cuando entraba a verme no sé cómo explicarlo... Miguel Delibes tiene una novela donde repite como un estribillo: "Su sola presencia aligeraba la pesadumbre de vivir"3. Bueno, pues eso era lo que sentía cuando pasaba a visitarme y me daba ánimos cogiéndome el brazo, porque tuve momentos muy bajos. Su delicado modo de manejar la información, poniendo en práctica la necesidad terapéutica ${ }^{4}$, para complementarla en el momento adecuado, me pareció ejemplar. Recuerdo la alegría que mi doctora tuvo el día que me encontró sentado en la butaca con las piernas cruzadas, como un lord, mirando al parque por la ventana, tras experimentar las primeras horas de mejoría. Cuando, tras darme el alta hospitalaria, le escribí un correo para contarle mi positiva evolución al cabo de una semana, me respondió que ella también estaba infectada y aislada en casa, que no se encontraba muy mal pero estaba preocupada por su marido y sus hijos. Maldito virus.

Como médico, en la primera fase de esta epidemia he estado prácticamente fuera de combate, pero como paciente siento el orgullo de tener los mejores profesionales del mundo trabajando en equipo, tanto en los hospitales como en los centros de salud, con una labor quizás más oculta, pero igualmente decisiva en este episodio que estamos viviendo, y que sin duda nos ha tocado en las fibras más íntimas de nuestro ser.

Rogelio Altisent Centro de Salud Actur Sur. IIS Aragón. Universidad de Zaragoza, España

\section{BIBLIOGRAFÍA}

1. McEwan I. Los perros negros. Barcelona: Anagrama; 1993.

2. Pérez-Bret E, Altisent R, Rocafort J. Definition of compassion in healthcare: a systematic literature review. Int J Palliat Nurs. 2016;22:599-605.

3. Delibes M. Señora de rojo sobre fondo gris. Barcelona: Destino; 1991.

4. Ley $41 / 2002$, de 14 de noviembre, Básica Reguladora de la Autonomía del paciente y de derechos y obligaciones en materia de información y documentación clínica. BOE n. ${ }^{\circ} 274$, de 15 de noviembre de 2002. Art. 5.4. 